\title{
Two family studies on congenital dislocation of the hip after early orthopaedic screening in Hungary
}

\author{
A. CZEIZEL,* J. SZENTPÉTERY,† G. TUSNÁDY,‡ and T. VIZKELETY**
}

Summary. Two family studies involving 1767 and 379 index patients in Budapest and Békés county, respectively, were undertaken to examine the effect of early orthopaedic screening on the recurrence risk of congenital dislocation of the hip. About $14 \%, 2.1-2.3 \%, 1.2-1.4 \%$, and $4.7-6.1 \%$ of sibs, parents, uncles and aunts, and cousins, respectively, had congenital dislocation of the hip in these two surveys. The recurrence risks were eight-fold and four-fold higher in brothers and sisters, four times higher in parents, 2.5-fold higher in uncles and aunts, and 2.0-2.5 times higher in cousins, respectively, than in the general population. This family pattern seems to fit best with a model of polygenic-multifactorial inheritance. In earlier studies higher recurrence risks were found. These may be explained by the change of diagnosis due to early orthopaedic screening which may increase the possibility of overdiagnosis and the treatment of mild cases which previously recovered spontaneously.

The incidence of treated congenital dislocation of the hip (CDH) was 27.5 per 1000 livebirths in Budapest from 1962 to 1967 (Czeizel, Vizkelety, and Szentpéteri, 1972) and 28.7 per 1000 livebirths in Békés county, Hungary from 1970 to 1972 (Czeizel, Szentpétery, and Kellermann, 1974). These conspicuously high values may be partly a true high incidence and partly the result of overdiagnosis in the course of extensive early orthopaedic screening. Our family studies involve 1767 index patients from Budapest and 379 index patients from Békés county. The purpose was to test the supposed polygenic inheritance of the cases of $\mathrm{CDH}$ (Carter and Wilkinson, 1964; Wynne-Davies, $1970 \mathrm{a} ; 1970 \mathrm{~b}$ ) and to examine the effect of early orthopaedic screening on the recurrence risk of $\mathrm{CDH}$.

\footnotetext{
Received 30 April 1974

* Laboratory of Human Genetics, National Institute of Public Health, Budapest, Hungary.

† Department of Orthopaedics, Hospital of Békés County, Békéscsaba, Hungary.

$¥$ Mathematical Institute of the Hungarian Academy of Sciences, Budapest, Hungary.

** Department of Orthopaedics, Semmelweis University of Medical Sciences, Budapest, Hungary.
}

\section{Material and methods}

In Budapest between 1962 and 1967, 3000 infants of 108966 livebirths received treatment for $\mathrm{CDH}$. A questionnaire was sent to the parents of each index patient, and another questionnaire to those who had not returned the first one. Thus, in 1767 cases $(58.9 \%$ of all the material) we determined the number of first-, second-, and third-degree relatives and the familial incidence of $\mathrm{CDH}$, as well as the occurrence of other congenital malformations.

This was followed by three control surveys. (1) Every case of $\mathrm{CDH}$ reported in first-degree relatives was checked personally by us and only those who received orthopaedic treatment were included as affected. (2) Of the 787 index patients who had sibs 150 boys and 150 girls were randomly selected and personally visited with three objectives. To check firstly, the epidemiological data of index patients published earlier (Czeizel et al, 1972); second, the number of first-, second- and thirddegree relatives, and third, to trace, through personal interview and examination, unreported cases of $\mathrm{CDH}$ in the family. As a rule, no significant discrepancy was found between the questionnaire and personal findings for the number of affected individuals in the family nor for epidemiological data. On the other hand, the number of healthy first-, second-, and third-degree relatives was often found to be greater than the number reported in the questionnaires. The interviews revealed that for uncles-aunts and cousins the under-reporting in the 
questionnaire was $5 \%$ and $11 \%$, respectively, on the maternal side, and $11 \%$ and $23 \%$, respectively, on the paternal side. A correction was made accordingly. In the third survey, twins were personally examined and after orthopaedic check-up the type of twinning was determined in like-sexed pairs on the basis of $\mathrm{A}_{1} \mathrm{~A}_{2} \mathrm{BO}$, Rh, MNSs, Lewis, Kell, Duffy, Kidd blood groups, haptoglobin, Gm, Inv serum protein groups, and dermatoglyphics.

Between 1970 and 1972, 18219 livebirths were registered in Békés county and from this population 523 index patients received orthopaedic treatment for radiologically verified CDH. The index patients and their first-degree relatives were personally examined in the orthopaedic ambulance. In all 379 families were studied.

Data of the family studies were processed by a computer. In the analysis and calculating the heritability value $\left(h^{2}\right)$ it had to be considered that parents, aunts, and uncles had not been subjected to an extensive neonatal screening similar to the one in use at the present time. So for them we took a livebirth estimated incidence of 9.0 per 1000 for females and 2.0 per 1000 for males (Pap, 1954). The $h^{2}$ value was calculated after the method of Falconer $(1965 ; 1967)$ using a modified table (Czeizel and Tusnády, 1972). $\lambda$ Exponents obtained from the exact, two-dimensional normal distribution (the operation was carried out using a CDC 3300 computer) were set up in a new table. Finally the recurrence risks of $\mathrm{CDH}$ for the Hungarian population were estimated adapting the computer program of Smith (1972).

\section{Results and discussion}

Data of family study in Budapest are given in Table I. Hungarian orthopaedists regard dys-

TABLE I

FREQUENCY OF CDH IN RELATIVES OF INDEX PATIENTS IN THE BUDAPEST SURVEY

\begin{tabular}{|c|c|c|c|c|c|c|c|c|c|}
\hline \multirow{3}{*}{ Relatives } & \multicolumn{9}{|c|}{ Type of Lesion } \\
\hline & \multicolumn{3}{|c|}{ Luxation-Subluxation } & \multicolumn{3}{|c|}{ Dysplasia } & \multicolumn{3}{|c|}{$\mathrm{CDH}$} \\
\hline & $\begin{array}{c}\text { Male } \\
\text { Index } \\
\text { Patients }\end{array}$ & $\begin{array}{c}\text { Female } \\
\text { Index } \\
\text { Patients }\end{array}$ & Total & $\begin{array}{c}\text { Male } \\
\text { Index } \\
\text { Patients }\end{array}$ & $\begin{array}{c}\text { Female } \\
\text { Index } \\
\text { Patients }\end{array}$ & Total & $\begin{array}{c}\text { Male } \\
\text { Index } \\
\text { Patients }\end{array}$ & $\begin{array}{c}\text { Female } \\
\text { Index } \\
\text { Patients }\end{array}$ & Total \\
\hline $\begin{array}{l}\text { Pathers } \\
\text { Total } \\
\text { Affected }\end{array}$ & $\begin{array}{l}80 \\
1(1.25 \%)\end{array}$ & $\begin{array}{l}394 \\
5(1.27 \%)\end{array}$ & $\begin{array}{l}474 \\
6(1.27 \%)\end{array}$ & $\begin{array}{l}342 \\
6(1.75 \%)\end{array}$ & $\begin{array}{l}951 \\
4(0.42 \%)\end{array}$ & $\begin{array}{l}1293 \\
10(0.77 \%)\end{array}$ & $\begin{array}{l}422 \\
7(1.66 \%)\end{array}$ & $\begin{array}{l}1345 \\
9(0.67 \%)\end{array}$ & $\begin{array}{l}1767 \\
16(0.91 \%)\end{array}$ \\
\hline $\begin{array}{l}\text { Mothers } \\
\text { Total } \\
\text { Affected }\end{array}$ & $\begin{array}{l}80 \\
7(8.75 \%)\end{array}$ & $\begin{array}{l}394 \\
19(4.82 \%)\end{array}$ & $\begin{array}{l}474 \\
26(5.49 \%)\end{array}$ & $\begin{array}{l}342 \\
13(3.80 \%)\end{array}$ & $\begin{array}{l}951 \\
27(2.84 \%)\end{array}$ & $\begin{array}{l}1293 \\
40(3.09 \%)\end{array}$ & $\begin{array}{l}422 \\
20(4.73 \%)\end{array}$ & $\begin{array}{l}1345 \\
46(3.42 \%)\end{array}$ & $\begin{array}{l}1767 \\
66(3.74 \%)\end{array}$ \\
\hline $\begin{array}{l}\text { Brothers } \\
\text { Total* } \\
\text { Affected }\end{array}$ & $\begin{array}{l}23(57) \\
3(13.04 \%)\end{array}$ & $\begin{array}{l}124(293) \\
17(13.71 \%)\end{array}$ & $\begin{array}{l}147(350) \\
20(13.61 \%)\end{array}$ & $\begin{array}{l}102(182) \\
17(16.67 \%)\end{array}$ & $\begin{array}{l}297(723) \\
12(4.04 \%)\end{array}$ & $\begin{array}{l}399(905) \\
29(7.27 \%)\end{array}$ & $\begin{array}{l}125(239) \\
20(16.00 \%)\end{array}$ & $\begin{array}{l}421(1016) \\
29(6.89 \%)\end{array}$ & $\begin{array}{l}546(1255) \\
49(8.97 \%)\end{array}$ \\
\hline $\begin{array}{l}\text { Sisters } \\
\text { Total } \\
\text { Affected }\end{array}$ & $\begin{array}{l}28(57) \\
3(10.71 \%)\end{array}$ & $\begin{array}{l}121(290) \\
37(30.58 \%)\end{array}$ & $\begin{array}{l}149(347) \\
40(26.85 \%)\end{array}$ & $\begin{array}{l}98(176) \\
17(17.35 \%)\end{array}$ & $\begin{array}{l}277(737) \\
42(15.16 \%)\end{array}$ & $\begin{array}{l}375(913) \\
59(15.73 \%)\end{array}$ & $\begin{array}{l}126(233) \\
20(15.87 \%)\end{array}$ & $\begin{array}{l}398(1027) \\
79(19.85 \%)\end{array}$ & $\begin{array}{l}524(1260) \\
99(18.89 \%)\end{array}$ \\
\hline $\begin{array}{l}\text { Fathers' br } \\
\text { Totalt } \\
\text { Affected }\end{array}$ & $\begin{array}{l}\text { others } \\
114(49) \\
1(0.88 \%)\end{array}$ & $\begin{array}{l}508(169) \\
0\end{array}$ & $\begin{array}{l}596(218) \\
1(0.17 \%)\end{array}$ & $\begin{array}{l}561(92) \\
1(0.18 \%)\end{array}$ & $\begin{array}{l}1168(422) \\
7(0.67 \%)\end{array}$ & $\begin{array}{l}1729(514) \\
8(0.46 \%)\end{array}$ & $\begin{array}{l}683(141) \\
2(0.29 \%)\end{array}$ & $\begin{array}{l}1696(591) \\
7(0.41 \%)\end{array}$ & $\begin{array}{l}2379(732) \\
9(0.38 \%)\end{array}$ \\
\hline $\begin{array}{l}\text { Fathers' si } \\
\text { Total } \\
\text { Affected }\end{array}$ & $\begin{array}{l}\text { ters } \\
110(30)\end{array}$ & $\begin{array}{l}468(190) \\
7(1.49 \%)\end{array}$ & $\begin{array}{l}578(220) \\
7(1.21 \%)\end{array}$ & $\begin{array}{l}499(110) \\
11(2.20 \%)\end{array}$ & $\begin{array}{l}1005(452) \\
18(1.79 \%)\end{array}$ & $\begin{array}{l}1504(562) \\
29(1.93 \%)\end{array}$ & $\begin{array}{l}609(140) \\
11(1.81 \%)\end{array}$ & $\begin{array}{l}1473(642) \\
25(1.70 \%)\end{array}$ & $\begin{array}{l}2082(782) \\
36(1.73 \%)\end{array}$ \\
\hline $\begin{array}{l}\text { Mothers' b } \\
\text { Totalt } \\
\text { Affected } \\
\end{array}$ & $\begin{array}{l}\text { others } \\
92(31) \\
5(5.43 \%) \\
\end{array}$ & $\begin{array}{l}499(151) \\
0\end{array}$ & $\begin{array}{l}591(182) \\
5(0.85 \%)\end{array}$ & $\begin{array}{l}469(88) \\
2(0.43 \%)\end{array}$ & $\begin{array}{l}1031(421) \\
5(0.48 \%)\end{array}$ & $\begin{array}{l}1500(509) \\
7(0.47 \%)\end{array}$ & $\begin{array}{l}563(119) \\
7(1.24 \%)\end{array}$ & $\begin{array}{l}1534(572) \\
5(0.33 \%)\end{array}$ & $\begin{array}{l}2097(691) \\
12(0.57 \%)\end{array}$ \\
\hline $\begin{array}{l}\text { Mothers' s } \\
\text { Totalt } \\
\text { Affected }\end{array}$ & $\begin{array}{l}\text { sters } \\
100(34) \\
1(1.00 \%)\end{array}$ & $\begin{array}{l}511(158) \\
23(4.50 \%) \\
\end{array}$ & $\begin{array}{l}611(192) \\
24(3.93 \%)\end{array}$ & $\begin{array}{l}500(99) \\
7(1.40 \%)\end{array}$ & $\begin{array}{l}1096(414) \\
32(2.92 \%)\end{array}$ & $\begin{array}{l}1596(513) \\
39(2.44 \%)\end{array}$ & $\begin{array}{l}601(133) \\
8(1.40 \%) \\
\end{array}$ & $\begin{array}{l}1611(572) \\
55(3.41 \%)\end{array}$ & $\begin{array}{l}2212(705) \\
63(2.85 \%)\end{array}$ \\
\hline $\begin{array}{l}\text { Paternal c } \\
\text { Totalt } \\
\text { Affected } \\
\end{array}$ & $\begin{array}{c}\text { usins (males) } \\
101(42) \\
4(3.96 \%) \\
\end{array}$ & $\begin{array}{l}540(244) \\
21(3.89 \%)\end{array}$ & $\begin{array}{l}641(286) \\
25(3.90 \%)\end{array}$ & $\begin{array}{l}501(142) \\
0\end{array}$ & $\begin{array}{l}1103(563) \\
29(2.63 \%)\end{array}$ & $\begin{array}{l}1604(705) \\
29(1.81 \%)\end{array}$ & $\begin{array}{l}601(18 \\
4(0.67 \%)\end{array}$ & $\begin{array}{l}1643(807) \\
50(3.04 \%) \\
\end{array}$ & $\begin{array}{l}2244(991) \\
54(2.41 \%) \\
\end{array}$ \\
\hline $\begin{array}{l}\text { Paternal c } \\
\text { Totalt } \\
\text { Affected }\end{array}$ & $\begin{array}{l}\text { usins (females) } \\
173(41) \\
11(6.36 \%)\end{array}$ & $\begin{array}{l}556(239) \\
33(5.94 \%)\end{array}$ & $\begin{array}{l}729(280) \\
44(6.04 \%)\end{array}$ & $\begin{array}{l}493(136) \\
47(9.53 \%)\end{array}$ & $\begin{array}{l}1081(597) \\
95(8.79 \%)\end{array}$ & $\begin{array}{l}1574(733) \\
142(9.02 \%)\end{array}$ & $\begin{array}{l}667(177) \\
58(8.70 \%)\end{array}$ & $\begin{array}{l}1637(836) \\
128(7.82 \%)\end{array}$ & $\begin{array}{l}2304(1013) \\
186(8.07 \%)\end{array}$ \\
\hline $\begin{array}{l}\text { Maternal } \\
\text { Totalt } \\
\text { Affected } \\
\end{array}$ & $\begin{array}{l}\text { ousins (males) } \\
81(50) \\
0\end{array}$ & $\begin{array}{l}446(223) \\
25(5.61 \%)\end{array}$ & $\begin{array}{l}527(273) \\
25(4.74 \%)\end{array}$ & $\begin{array}{l}463(130) \\
7(1.51 \%)\end{array}$ & $\begin{array}{l}887(594) \\
27(3.04 \%)\end{array}$ & $\begin{array}{l}1350(724) \\
34(2.52 \%)\end{array}$ & $\begin{array}{l}544(180) \\
7(1.29 \%)\end{array}$ & $\begin{array}{l}1333(817) \\
52(3.90 \%)\end{array}$ & $\begin{array}{l}1877(997) \\
59(3.14 \%)\end{array}$ \\
\hline $\begin{array}{l}\text { Maternal } \\
\text { Totalt } \\
\text { Afiected }\end{array}$ & $\begin{array}{c}\text { ousins (females } \\
103(38) \\
9(8.74 \%)\end{array}$ & $\begin{array}{l}435(223) \\
53(12.18 \%)\end{array}$ & $\begin{array}{l}538(261) \\
62(11.52 \%)\end{array}$ & $\begin{array}{l}441(132) \\
26(5.90 \%)\end{array}$ & $\begin{array}{l}847(599) \\
119(14.05 \%)\end{array}$ & $\begin{array}{l}1288(731) \\
145(11.26 \%)\end{array}$ & $\begin{array}{l}544(170) \\
35(6.43 \%)\end{array}$ & $\begin{array}{l}1282(822) \\
172(13.42 \%)\end{array}$ & $\begin{array}{l}1826(992) \\
207(11.34 \%)\end{array}$ \\
\hline
\end{tabular}

* The number of index patients with no sibs is given in parentheses.

$t$ The number of second- and third-degree relatives of unknown status is given in parentheses. 
plasia as the precursor of luxation, thus probably the milder cases have been put in the dysplasia group and the majority of overdiagnosed cases would be in this group. The evaluation should be based mainly upon the incidence of $\mathrm{CDH}$ in first-degree relatives as these data were personally checked, and according to the representative sample of 300 persons practically no cases of $\mathrm{CDH}$ had remained unreported. The most important results of family study in Békés county are summarized in Table II. The frequencies of affected relatives show an essential similarity in both surveys. Only two deviations seem to appear in first-degree relatives: the frequency of the affected mothers and affected sibs of male index patients differ in the two studies.

Using the polygenic model for the recurrence of CDH (Edwards, 1960a; 1960b; Carter, 1965), the

TABLE II

FREQUENCY OF CDH IN RELATIVES OF INDEX PATIENTS IN THE BÉKÉS COUNTY SURVEY

\begin{tabular}{|c|c|c|c|}
\hline \multirow{2}{*}{ Relatives } & \multicolumn{3}{|c|}{ Index Patients } \\
\hline & Males $(n=75)$ & $\begin{array}{c}\text { Females } \\
(\mathrm{n}=304)\end{array}$ & Total $(n=379)$ \\
\hline $\begin{array}{l}\text { Fathers } \\
\text { Total } \\
\text { Affected }\end{array}$ & $\begin{array}{l}75 \\
1(1.33 \%)\end{array}$ & $\begin{array}{l}304 \\
0\end{array}$ & $\begin{array}{l}379 \\
1(0.26 \%)\end{array}$ \\
\hline $\begin{array}{l}\text { Mothers } \\
\text { Total } \\
\text { Affected }\end{array}$ & $\begin{array}{l}75 \\
2(2.67 \%)\end{array}$ & $\begin{array}{l}304 \\
13(4.28 \%)\end{array}$ & $\begin{array}{l}379 \\
15(3.95 \%)\end{array}$ \\
\hline $\begin{array}{l}\text { Fathers and moth } \\
\text { Total } \\
\text { Affected }\end{array}$ & ${ }_{3}{ }_{3}$ & $\begin{array}{l}608 \\
13\end{array}$ & $\begin{array}{l}758 \\
16(2.11 \%)\end{array}$ \\
\hline $\begin{array}{l}\text { Brothers } \\
\text { Total } \\
\text { Affected }\end{array}$ & $\begin{array}{l}22 \\
2(9.09 \%)\end{array}$ & $\begin{array}{l}89 \\
6(6.75 \%)\end{array}$ & $\begin{array}{l}111 \\
8(7.20 \%)\end{array}$ \\
\hline $\begin{array}{l}\text { Sisters } \\
\text { Total } \\
\text { Affected }\end{array}$ & $\begin{array}{l}21 \\
7(33.33 \%)\end{array}$ & $\begin{array}{l}75 \\
14(18.67 \%)\end{array}$ & $\begin{array}{l}96 \\
21(21.87 \%)\end{array}$ \\
\hline $\begin{array}{l}\text { Brothers and Sist } \\
\text { Total } \\
\text { Affected }\end{array}$ & $\begin{array}{l}r s \\
\quad 43 \\
9(20.93 \%)\end{array}$ & $\begin{array}{l}164 \\
20(12.20 \%)\end{array}$ & $\begin{array}{l}207 \\
29(14.01 \%)\end{array}$ \\
\hline $\begin{array}{l}\text { Uncles } \\
\text { Total } \\
\text { Affected }\end{array}$ & $\begin{array}{l}120 \\
0\end{array}$ & $\begin{array}{l}546 \\
3(0.55 \%)\end{array}$ & $\begin{array}{l}666 \\
3(0.45 \%)\end{array}$ \\
\hline $\begin{array}{l}\text { Aunts } \\
\text { Total } \\
\text { Affected }\end{array}$ & $\begin{array}{l}91 \\
0\end{array}$ & $\begin{array}{l}527 \\
12(2.28 \%)\end{array}$ & $\begin{array}{l}618 \\
12(1.94 \%)\end{array}$ \\
\hline $\begin{array}{l}\text { Uncles and aunts } \\
\text { Total } \\
\text { Affected }\end{array}$ & $\begin{array}{l}211 \\
0\end{array}$ & $\begin{array}{l}1073 \\
15(1.40 \%)\end{array}$ & $\begin{array}{l}1284 \\
15(1.17 \%)\end{array}$ \\
\hline $\begin{array}{l}\text { Male cousins } \\
\text { Total } \\
\text { Affected }\end{array}$ & $\begin{array}{l}84 \\
2(2.38 \%)\end{array}$ & $\begin{array}{l}394 \\
8(2.51 \%)\end{array}$ & $\begin{array}{l}478 \\
10(2.09 \%)\end{array}$ \\
\hline $\begin{array}{l}\text { Female cousins } \\
\text { Total } \\
\text { Affected }\end{array}$ & $\begin{array}{l}89 \\
12(13.48 \%)\end{array}$ & $\begin{array}{l}407 \\
24(5.89 \%)\end{array}$ & $\begin{array}{l}496 \\
36(7.25 \%)\end{array}$ \\
\hline $\begin{array}{l}\text { Male and female } \\
\text { Total } \\
\text { Affected }\end{array}$ & $\begin{array}{l}\text { ousins } \\
173 \\
14(8.09 \%)\end{array}$ & $\begin{array}{l}801 \\
32(3.99 \%)\end{array}$ & $\begin{array}{l}974 \\
\mathbf{4 6}(4.72 \%)\end{array}$ \\
\hline
\end{tabular}

sex- and age-modified expected values and the observed values expressed in percentage are shown in Table III.

In Budapest $13.83 \%$ and in Békés $14.01 \%$ of sibs of all index patients have $\mathrm{CDH}$. In sibs the actual recurrence risk was near to the expected value. The figures show that for male index patients the recurrence risk was the same for brothers and sisters in the Budapest survey (in the luxation-subluxation group the proportion of affected brothers was higher, for the sibs of male index patients the recurrence rate was higher in the dysplasia group). In Békés county, however, there were more affected sisters than brothers of male index patients, but the female excess was less than that for all $\mathrm{CDH}$ subjects in this survey. The incidence of $\mathrm{CDH}$ in brothers and sisters increased eight-fold and four-fold, respectively, over the population incidence (P). The doubled risk among brothers was obvious in both surveys. Recurrence risk is the highest for brothers of male index patients, being 11-12 times higher than $P$. The brothers of female patients also have a higher risk (six times over $P$ ) than their sisters (four times over $\mathrm{P}$ ). Finally, $\mathrm{CDH}$ was found more frequently in the sisters of male patients (seven times over $P$ ) than in the sisters of female patients (four times over $\mathrm{P}$ ) in the Békés survey.

The rate of affected parents was found to be $2.32 \%$ and $2.11 \%$ in the Budapest and Békés surveys, respectively. In parents a fairly marked discrepancy was found between the expected and the observed values of recurrence risk. In fathers and mothers of the index patients the incidence of $\mathrm{CDH}$ was four time higher than the population incidence. The fathers of male index patients were more frequently affected (eight times over P) than the mothers (four times over P). In the luxationsubluxation group which include the more serious cases the frequency of $\mathrm{CDH}$ was somewhat higher in parents.

The incidence among uncles and aunts of index patients was $1.36 \%$ and $1.17 \%$, in these two surveys. In uncles and aunts the sex ratio of $\mathrm{CDH}$ cases was usually $1: 4-5$ in both surveys and the overall incidence of $\mathrm{CDH}$ was 2.5 times higher than in the general population. The greater number of affected relatives on the maternal side $(50 \%$ higher incidence) in the Budapest survey could be the town dwellers' greater awareness of the condition.

The incidence in cousins of index patients was 6.1 and $4.7 \%$ in the two surveys. Among cousins 2.5$3.5 \%$ of the boys and $6.0-13.5 \%$ of the girls were affected. They belonged to the age group which had extensive neonatal screening and so in their cases 
TABLE III

HERITABILITY OF CDH

\begin{tabular}{|c|c|c|c|c|c|c|c|c|c|c|c|c|c|}
\hline & & & & \multicolumn{8}{|c|}{ Relatives } & & \\
\hline \multicolumn{3}{|c|}{ Index Patients } & & \multicolumn{3}{|c|}{ Parameters } & \multicolumn{2}{|c|}{$\begin{array}{c}\text { Expected } \\
\text { Values }\end{array}$} & \multicolumn{3}{|c|}{ Observed Values } & \multicolumn{2}{|c|}{ Heritability } \\
\hline Survey & $\mathbf{P}(\%)$ & L & & $\mathbf{P}(\%)$ & $\mathbf{k}$ & $r$ & $\lambda$ & $q(\%)$ & $\lambda$ & $\mathbf{q}(\%)$ & $\mathbf{q} / \mathbf{P}$ & b & $\mathbf{h}^{2}$ \\
\hline $\begin{array}{l}\text { Males } \\
\text { Budapest }\end{array}$ & 13.6 & 2.21 & $\begin{array}{l}\text { Father } \\
\text { Mother } \\
\text { Brother } \\
\text { Sister } \\
\text { Uncle } \\
\text { Aunt } \\
\text { Male cousin } \\
\text { Female cousin }\end{array}$ & $\begin{array}{l}0.20 \\
0.90 \\
1.36 \\
4.25 \\
0.20 \\
0.90 \\
1.36 \\
4.25\end{array}$ & $\begin{array}{l}2.88 \\
2.37 \\
2.21 \\
1.72 \\
2.88 \\
2.37 \\
2.21 \\
1.72\end{array}$ & $\begin{array}{l}0.5 \\
0.5 \\
0.5 \\
0.5 \\
0.25 \\
0.25 \\
0.125 \\
0.125\end{array}$ & $\begin{array}{l}0.542 \\
0.474 \\
0.450 \\
0.383 \\
0.731 \\
0.695 \\
0.826 \\
0.802\end{array}$ & $\begin{array}{r}3.3 \\
10.6 \\
14.5 \\
29.4 \\
1.0 \\
3.7 \\
2.9 \\
7.9\end{array}$ & $\begin{array}{l}0.658 \\
0.648 \\
0.427 \\
0.583 \\
0.795 \\
0.886 \\
0 . \overline{-822}\end{array}$ & $\begin{array}{r}1.70 \\
4.75 \\
16.00 \\
15.87 \\
0.72 \\
1.56 \\
0.93 \\
7.42\end{array}$ & $\begin{array}{r}8.4 \\
5.3 \\
11.8 \\
3.7 \\
3.6 \\
1.7 \\
0.7 \\
1.7\end{array}$ & $\begin{array}{l}0.32 \\
0.28 \\
0.53 \\
0.30 \\
0.17 \\
0.08 \\
0.00 \\
0.11\end{array}$ & 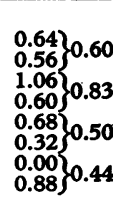 \\
\hline Békés & 8.1 & 2.40 & $\begin{array}{l}\text { Father } \\
\text { Mother } \\
\text { Brother } \\
\text { Sister } \\
\text { Uncle } \\
\text { Aunt } \\
\text { Male cousin } \\
\text { Female cousin }\end{array}$ & $\begin{array}{l}0.20 \\
0.90 \\
0.81 \\
5.06 \\
0.20 \\
0.90 \\
0.81 \\
5.06\end{array}$ & $\begin{array}{l}2.88 \\
2.40 \\
2.40 \\
1.64 \\
2.88 \\
2.37 \\
2.40 \\
1.64\end{array}$ & $\begin{array}{l}0.5 \\
0.5 \\
0.5 \\
0.5 \\
0.25 \\
0.25 \\
0.125 \\
0.125\end{array}$ & $\begin{array}{l}0.509 \\
0.439 \\
0.444 \\
0.329 \\
0.712 \\
0.675 \\
0.823 \\
0.786\end{array}$ & $\begin{array}{r}4.1 \\
12.5 \\
11.7 \\
37.4 \\
1.1 \\
4.1 \\
1.9 \\
9.5\end{array}$ & $\begin{array}{l}0.696 \\
0.771 \\
0.498 \\
0.369 \\
\overline{-} \\
0 . \overline{777} \\
0.672\end{array}$ & $\begin{array}{r}1.33 \\
2.67 \\
9.09 \\
33.33 \\
0.00 \\
0.00 \\
2.38 \\
13.48 \\
\end{array}$ & $\begin{array}{r}6.7 \\
3.0 \\
11.2 \\
6.6 \\
0.0 \\
0.0 \\
2.9 \\
2.7\end{array}$ & $\begin{array}{l}0.27 \\
0.16 \\
0.44 \\
0.45 \\
0.00 \\
0.00 \\
0.16 \\
0.20\end{array}$ & $\left.\begin{array}{l}\left.\begin{array}{l}0.54 \\
0.32\end{array}\right\} 0.44 \\
0.88 \\
0.90 \\
0.00 \\
0.00 \\
1.28 \\
1.60\end{array}\right\} 1.44$ \\
\hline $\begin{array}{l}\text { Females } \\
\text { Budapest }\end{array}$ & 42.5 & 1.72 & $\begin{array}{l}\text { Father } \\
\text { Mother } \\
\text { Brother } \\
\text { Sister } \\
\text { Uncle } \\
\text { Aunt } \\
\text { Male cousin } \\
\text { Female cousin }\end{array}$ & $\begin{array}{l}0.20 \\
0.90 \\
1.36 \\
4.25 \\
0.20 \\
0.90 \\
1.36 \\
4.25\end{array}$ & $\begin{array}{l}2.88 \\
2.37 \\
2.21 \\
1.72 \\
2.88 \\
2.37 \\
2.21 \\
1.72\end{array}$ & $\begin{array}{l}0.5 \\
0.5 \\
0.5 \\
0.5 \\
0.25 \\
0.25 \\
0.125 \\
0.125\end{array}$ & $\begin{array}{l}0.631 \\
0.567 \\
0.545 \\
0.471 \\
0.778 \\
0.747 \\
0.855 \\
0.836\end{array}$ & $\begin{array}{r}2.0 \\
6.9 \\
9.6 \\
20.4 \\
0.8 \\
2.9 \\
2.5 \\
7.1\end{array}$ & $\begin{array}{l}0.806 \\
0.718 \\
0.622 \\
0.534 \\
0.903 \\
0.778 \\
0.793 \\
0.733\end{array}$ & $\begin{array}{r}0.67 \\
3.43 \\
6.89 \\
19.85 \\
0.37 \\
2.58 \\
3.31 \\
9.92\end{array}$ & $\begin{array}{l}3.4 \\
3.8 \\
5.1 \\
4.7 \\
1.9 \\
2.9 \\
2.4 \\
2.3\end{array}$ & $\begin{array}{l}0.20 \\
0.27 \\
0.40 \\
0.42 \\
0.09 \\
0.20 \\
0.19 \\
0.22\end{array}$ & 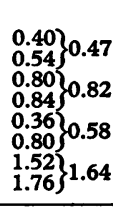 \\
\hline Békés & 50.6 & 1.64 & $\begin{array}{l}\text { Father } \\
\text { Mother } \\
\text { Brother } \\
\text { Sister } \\
\text { Uncle } \\
\text { Aunt } \\
\text { Male cousin } \\
\text { Female cousin }\end{array}$ & $\begin{array}{l}0.20 \\
0.90 \\
0.81 \\
5.06 \\
0.20 \\
0.90 \\
0.81 \\
5.06\end{array}$ & $\begin{array}{l}2.88 \\
2.37 \\
2.40 \\
1.64 \\
2.88 \\
2.37 \\
2.40 \\
1.64\end{array}$ & $\begin{array}{l}0.5 \\
0.5 \\
0.5 \\
0.5 \\
0.25 \\
0.25 \\
0.125 \\
0.125\end{array}$ & $\begin{array}{l}0.645 \\
0.582 \\
0.586 \\
0.475 \\
0.786 \\
0.754 \\
0.866 \\
0.857\end{array}$ & $\begin{array}{r}1.7 \\
6.5 \\
5.9 \\
24.2 \\
0.7 \\
2.8 \\
1.5 \\
7.7\end{array}$ & $\begin{array}{l}0 . \overline{6} 0 \\
0.560 \\
0.563 \\
0.838 \\
0.805 \\
0.765 \\
0.949\end{array}$ & $\begin{array}{r}0.00 \\
4.28 \\
6.75 \\
18.67 \\
0.55 \\
2.28 \\
2.51 \\
5.89\end{array}$ & $\begin{array}{l}0.0 \\
4.8 \\
8.3 \\
3.7 \\
2.8 \\
2.5 \\
3.1 \\
1.2\end{array}$ & $\begin{array}{l}0.00 \\
0.37 \\
0.54 \\
0.39 \\
0.17 \\
0.18 \\
0.22 \\
0.04\end{array}$ & 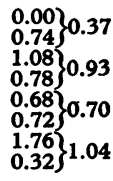 \\
\hline
\end{tabular}

$\mathbf{P}=$ incidence of population; $\mathrm{L}=$ threshold; $\mathrm{k}=$ specific population threshold relating to relevant incidence and sex; $r=$ correlation coefficient of relationship; $q=$ affected rate of relatives of index patients; $b=$ regression coefficient; $h^{2}=$ heritability; $\lambda$ exponent $=\frac{\log q}{\log p}$.

we did not comply with the definition that only treated cases of $\mathrm{CDH}$ would be taken into account. The incidence in cousins was 2.0-2.5 times higher than in the general population with a usual sex ratio of the affected persons.

Other malformations in the first-, second-, and third-degree relatives of index patients did not occur more frequently than in the general population.

Since, in 1882, Krönlein published some pedigrees of $\mathrm{CDH}$, several reports have proved the familial clustering of CDH (Muller and Seddon, 1953; Record and Edwards, 1958; Carter and Wilkinson, 1964; Woolf, Koehn, and Coleman, 1968; WynneDavis, 1970a). These studies reported more familial clustering in first-degree relatives including sibs than in our series. Several factors may account for this. Firstly, the extensive use of neonatal screening may increase the possibility of overdiagnosing the index patients. Also some mild cases who receive treatment now would previously have re- covered spontaneously and because of their less severe genetic burden the recurrence risk would also be less. In the Hungarian population the actual incidence of $\mathrm{CDH}$ is high and thus the threshold may be lower, than for example in the United Kingdom (Czeizel et al, 1972) and thus the frequency of recurrence may be relatively lower.

According to the model of polygenic inheritance the more severe the malformation the greater the risk of recurrence. Bearing this in mind our material has been divided into luxation-subluxation and dysplasia groups, and indeed the recurrence rates observed seem to agree with this theory.

Another characteristic feature of the polygenic model is that the recurrence risk greatly increases with the number of close relatives affected. Our material included four families with three affected sibs in each; not even one unaffected child occurred in these families.

Parental consanguinity was 2.8 per 1000 in our material. In the '70s the frequency of first-cousin 
marriages was 2.9 per 1000 in Hungary (Czeizel et al, 1975) therefore the consanguinity rate of $\mathrm{CDH}$ parents does not seem to be higher than the average.

Heritability is different in adult and child populations (Table III). The estimate from parents of index males and females is about 0.50 and 0.40 , respectively. The estimate for uncles and aunts is about 0.60 . But we have an estimate of 0.87 for sibs. This value was 0.82 and 0.93 in the Budapest and Békés surveys, respectively. Absurdly high rates were found in cousins. The disparity of definition of $\mathrm{CDH}$ may account for the latter.

Out of 21 twin pairs, 11 were dizygotic and six were very likely monozygotic. In four pairs the type of zygosity and the diagnosis of $\mathrm{CDH}$ could not be established because of stillbirth or early death. Three monozygotic pairs were found concordant. All the dizygotic twins were discordant and three of the six monozygotic pairs, that is $50 \%$, were con- cordant. Our findings show evidence of inheritance corresponding to previous reports ( $c f$, Idelberger, 1951).

Finally using the Budapest data and adapting the computer model of Smith (1972) Table IV was made to estimate the recurrence risk of $\mathrm{CDH}$. This has proved useful in genetic counselling and in the evaluation of symptoms during neonatal and early infant orthopaedic screening.

A characteristic familial clustering of the $\mathrm{CDH}$ cases could also be observed in the Hungarian population, which shows a conspicuously high incidence of $\mathrm{CDH}$. Coming back to the purpose of our study it may be stated that the familial patterns seem to fit best with the model of polygenic inheritance. But the change of diagnosis due to early orthopaedic screening has caused a 'dilution' of $\mathrm{CDH}$ casesit picks up mild cases which in general recover spontaneously and increases the possibility of

TABLE IV

RECURRENCE RISKS OF CDH

(Incidence: male 13.61 per 1000 ; female 42.48 per 1000 . Heritability: male $83 \%$; female $82 \%$.)

\begin{tabular}{|c|c|c|c|c|c|c|c|c|c|c|c|}
\hline \multicolumn{4}{|c|}{ Children } & \multicolumn{8}{|c|}{ Parents } \\
\hline \multicolumn{2}{|c|}{$\begin{array}{c}\text { Affected } \\
\text { Male }\end{array}$} & \multicolumn{2}{|c|}{$\begin{array}{l}\text { Affected } \\
\text { Female }\end{array}$} & \multicolumn{2}{|c|}{ Both Unaffected } & \multicolumn{2}{|c|}{ Affected Mother } & \multicolumn{2}{|c|}{ Affected Father } & \multicolumn{2}{|c|}{ Both Affected } \\
\hline No & Yes & No & Yes & $\begin{array}{c}\text { Female } \\
\text { Offspring }\end{array}$ & $\begin{array}{c}\text { Male } \\
\text { Offspring }\end{array}$ & $\begin{array}{c}\text { Female } \\
\text { Offspring }\end{array}$ & $\begin{array}{c}\text { Male } \\
\text { Offspring }\end{array}$ & $\begin{array}{c}\text { Female } \\
\text { Offspring }\end{array}$ & $\begin{array}{c}\text { Male } \\
\text { Offspring }\end{array}$ & $\begin{array}{c}\text { Female } \\
\text { Offspring }\end{array}$ & $\begin{array}{c}\text { Male } \\
\text { Offspring }\end{array}$ \\
\hline No chi & ld bor & $\begin{array}{l}\text { yet } \\
0\end{array}$ & 0 & 0.0359 & 0.0103 & 0.1766 & 0.0721 & 0.2190 & 0.0943 & 0.5843 & 0.3647 \\
\hline \begin{tabular}{c|c} 
One ch \\
1 \\
0 \\
0 \\
0
\end{tabular} & $\begin{array}{c}\text { bild bo } \\
0 \\
1 \\
0 \\
0\end{array}$ & \begin{tabular}{c|}
$n$ and \\
0 \\
0 \\
1 \\
0
\end{tabular} & $\begin{array}{c}\text { amon } \\
0 \\
0 \\
0 \\
1\end{array}$ & $\begin{array}{l}\text { them } \\
0.0345 \\
0.1715 \\
0.0322 \\
0.1356\end{array}$ & $\begin{array}{l}0.0097 \\
0.0663 \\
0.0088 \\
0.0492\end{array}$ & $\begin{array}{l}0.1635 \\
0.3453 \\
0.1503 \\
0.2992\end{array}$ & $\begin{array}{l}0.0643 \\
0.1717 \\
0.0573 \\
0.1409\end{array}$ & $\begin{array}{l}0.2028 \\
0.3748 \\
0.1872 \\
0.3323\end{array}$ & $\begin{array}{l}0.0842 \\
0.1908 \\
0.0755 \\
0.1613\end{array}$ & $\begin{array}{l}0.5491 \\
0.6458 \\
0.5297 \\
0.6232\end{array}$ & $\begin{array}{l}0.3291 \\
0.4267 \\
0.3107 \\
0.4030\end{array}$ \\
\hline \begin{tabular}{c|c}
$T w o$ & $c$ \\
2 \\
1 \\
1 \\
1 \\
0 \\
0 \\
0 \\
0 \\
0 \\
0
\end{tabular} & \begin{tabular}{c|} 
hildrer \\
0 \\
1 \\
0 \\
0 \\
2 \\
1 \\
1 \\
0 \\
0 \\
0
\end{tabular} & \begin{tabular}{c|} 
born \\
0 \\
0 \\
1 \\
0 \\
0 \\
1 \\
0 \\
2 \\
1 \\
0
\end{tabular} & $\begin{array}{c}\text { and } a \text { ar } \\
0 \\
0 \\
0 \\
1 \\
0 \\
0 \\
1 \\
0 \\
1 \\
2\end{array}$ & $\begin{array}{c}\text { ng them } \\
0.0332 \\
0.1625 \\
0.0311 \\
0.1289 \\
0.2989 \\
0.1521 \\
0.2653 \\
0.0292 \\
0.1206 \\
0.2315\end{array}$ & $\begin{array}{l}0.0092 \\
0.0614 \\
0.0084 \\
0.0458 \\
0.1360 \\
0.0561 \\
0.1156 \\
0.0077 \\
0.0418 \\
0.0962\end{array}$ & $\begin{array}{l}0.1528 \\
0.3193 \\
0.1413 \\
0.2773 \\
0.4708 \\
0.2991 \\
0.4329 \\
0.1311 \\
0.2589 \\
0.3935\end{array}$ & $\begin{array}{l}0.0583 \\
0.1524 \\
0.0524 \\
0.1256 \\
0.2648 \\
0.1388 \\
0.2341 \\
0.0473 \\
0.1140 \\
0.2039\end{array}$ & $\begin{array}{l}0.1893 \\
0.3487 \\
0.1756 \\
0.3095 \\
0.4851 \\
0.3289 \\
0.4512 \\
0.1633 \\
0.2908 \\
0.4157\end{array}$ & $\begin{array}{l}0.0762 \\
0.1710 \\
0.0588 \\
0.1448 \\
0.2750 \\
0.1572 \\
0.2470 \\
0.0623 \\
0.1326 \\
0.2190\end{array}$ & $\begin{array}{l}0.5196 \\
0.6092 \\
0.5026 \\
0.5872 \\
0.6950 \\
0.5898 \\
0.6765 \\
0.4866 \\
0.5680 \\
0.6565\end{array}$ & $\begin{array}{l}0.3006 \\
0.3872 \\
0.2852 \\
0.3651 \\
0.4798 \\
0.3674 \\
0.4592 \\
0.2710 \\
0.3460 \\
0.4375\end{array}$ \\
\hline \begin{tabular}{c|} 
Three \\
3 \\
2 \\
2 \\
2 \\
2 \\
1 \\
1 \\
1 \\
1 \\
1 \\
1 \\
0 \\
0 \\
0 \\
0 \\
0 \\
0 \\
0 \\
0 \\
0 \\
0
\end{tabular} & \begin{tabular}{l|} 
childr \\
0 \\
1 \\
0 \\
0 \\
2 \\
1 \\
1 \\
0 \\
0 \\
0 \\
3 \\
2 \\
2 \\
1 \\
1 \\
1 \\
0 \\
0 \\
0 \\
0
\end{tabular} & 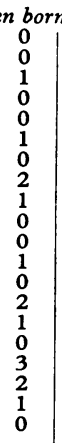 & $\begin{array}{c}\text { and } \\
0 \\
0 \\
0 \\
1 \\
0 \\
0 \\
1 \\
0 \\
1 \\
2 \\
0 \\
0 \\
1 \\
0 \\
1 \\
2 \\
0 \\
1 \\
2 \\
3\end{array}$ & $\begin{array}{c}\text { nong them } \\
0.0321 \\
0.1546 \\
0.0301 \\
0.1230 \\
0.2834 \\
0.1452 \\
0.2518 \\
0.0284 \\
0.1155 \\
0.2200 \\
0.3974 \\
0.2692 \\
0.3686 \\
0.1366 \\
0.2386 \\
0.3392 \\
0.0268 \\
0.1086 \\
0.2080 \\
0.3094\end{array}$ & $\begin{array}{l}0.0088 \\
0.0572 \\
0.0080 \\
0.0428 \\
0.1257 \\
0.0525 \\
0.1070 \\
0.0074 \\
0.0393 \\
0.0894 \\
0.2017 \\
0.1169 \\
0.1809 \\
0.0484 \\
0.0993 \\
0.1606 \\
0.0069 \\
0.0362 \\
0.0827 \\
0.1410\end{array}$ & $\begin{array}{l}0.1438 \\
0.2979 \\
0.1336 \\
0.2592 \\
0.4383 \\
0.2801 \\
0.4029 \\
0.1245 \\
0.2431 \\
0.3664 \\
0.5609 \\
0.4171 \\
0.5310 \\
0.2636 \\
0.3823 \\
0.4991 \\
0.1164 \\
0.2282 \\
0.3468 \\
0.4654\end{array}$ & $\begin{array}{l}0.0534 \\
0.1372 \\
0.0483 \\
0.1136 \\
0.2367 \\
0.1257 \\
0.2092 \\
0.0439 \\
0.1038 \\
0.1825 \\
0.3430 \\
0.2197 \\
0.3155 \\
0.1154 \\
0.1936 \\
0.2872 \\
0.0401 \\
0.0951 \\
0.1684 \\
0.2586\end{array}$ & $\begin{array}{l}0.1780 \\
0.3268 \\
0.1658 \\
0.2903 \\
0.4550 \\
0.3090 \\
0.4228 \\
0.1548 \\
0.2736 \\
0.3895 \\
0.5644 \\
0.4354 \\
0.5378 \\
0.2923 \\
0.4036 \\
0.5092 \\
0.1448 \\
0.2581 \\
0.3707 \\
0.4790\end{array}$ & $\begin{array}{l}0.0697 \\
0.1550 \\
0.0633 \\
0.1316 \\
0.2486 \\
0.1431 \\
0.2231 \\
0.0577 \\
0.1211 \\
0.1979 \\
0.3446 \\
0.2326 \\
0.3200 \\
0.1322 \\
0.2081 \\
0.2944 \\
0.0527 \\
0.1115 \\
0.1840 \\
0.2683\end{array}$ & $\begin{array}{l}0.4945 \\
0.5780 \\
0.4793 \\
0.5568 \\
0.6585 \\
0.5611 \\
0.6400 \\
0.4648 \\
0.5400 \\
0.6203 \\
0.7345 \\
0.6393 \\
0.7194 \\
0.5452 \\
0.6209 \\
0.7031 \\
0.4509 \\
0.5243 \\
0.6012 \\
0.6855\end{array}$ & $\begin{array}{l}0.2772 \\
0.3550 \\
0.2640 \\
0.3344 \\
0.4381 \\
0.3383 \\
0.4185 \\
0.2517 \\
0.3183 \\
0.3979 \\
0.5250 \\
0.4175 \\
0.5071 \\
0.3231 \\
0.3983 \\
0.4883 \\
0.2401 \\
0.3037 \\
0.3782 \\
0.4685\end{array}$ \\
\hline
\end{tabular}


overdiagnosis-therefore the recurrence risks of $\mathrm{CDH}$ have decreased relative to the population incidence.

The authors wish to express their gratitude to C. O. Carter and K. Evans (MRC, Clinical Genetics Unit, Institute of Child Health, London) for their criticism and constructive advice.

\section{RBFBRENCRS}

Carter, C. O. (1965). The inheritance of common congenital malformations. In Progress in Medical Genetics, vol. 4, ed. by A. G. Steinberg and A. G. Bearn, pp. 59-84. Grune and Stratton, New York.

Carter, C. O. and Wilkinson, J. A. (1964). Genetic and environmental factors in the etiology of congenital dislocation of the hip. Clinical Orthopaedics, 33, 119-128.

Czeizel, A., Bodnár, L., Illei, G., and Molnár, L. (1975). Consanguinity in Hungary. Human Heredity. (In press.)

Czeizel, A., Szentpétery, J., and Kellermann, M. (1974). Recent study on the incidence of congenital dislocation of the hip in Hungary. British fournal of Preventive and Social Medicine. (In press.)

Czeizel, A. and Tusnády, G. (1972). A family study on cleft lip with or without cleft palate and posterior cleft palate in Hungary. Human Heredity, 22, 405-416.

Czeizel, A., Vizkelety, T., and Szentpéteri, J. (1972). Congenital dislocation of the hip in Budapest, Hungary. British fournal of Preventive and Social Medicine, 26, 15-22.
Edwards, J. H. (1960a). The simulation of Mendelism. Acta Genetica et Statistica Medica, 10, 63-70.

Edwards, J. H. (1960b). Cited in Carter, C. O. (1965).

Falconer, D. S. (1965). The inheritance of liability to certain diseases, estimated from the incidence among relatives. Annals of Human Genetics, 29, 51-76.

Falconer, D. S. (1967). The inheritance of liability to certain diseases with variable age of onset, with particular reference to diabetes mellitus. Annals of Human Genetics, 31, 1-20.

Idelberger, K. (1951). Die Erbpathologie der sogennanten angeborenen Hïftverrenkung. Urban and Schwartzenberg, Munich.

Krönlein, R. U. (1882). Die Lehre von den Luxationen. Enke, Stuttgart.

Muller, G. M. and Seddon, H. J. (1953). Late results of treatment of congenital dislocation of the hip. fournal of Bone and foint Surgery, 35B, 342-362.

Pap, K. (1954). Studies on congenital dislocation of the hip in Tiszántul. (In Hungarian.) Népegészségügy, 35, 72-75.

Record, R. G. and Edwards, J. H. (1958). Environmental influences related to the aetiology of congenital dislocation of the hip. British Fournal of Preventive and Social Medicine, 12, 8-22.

Smith, C. (1972). Computer programme to estimate recurrence risks for multifactorial familial disease. British Medical fournal, $1,495-497$.

Woolf, C. M., Koehn, J. H., and Coleman, S. S. (1968). Congenital hip disease in Utah: the influence of genetic and nongenetic factors. American fournal of Human Genetics, 20, 430-439.

Wynne-Davies, R. (1970a). A family study of neonatal and late diagnosis congenital dislocation of the hip. Fournal of Medical Genetics, 7, 315-333.

Wynne-Davies, R. (1970b). Acetabular dysplasia and familial joint laxity: two etiological factors in congenital dislocation of the hip fournal of Bone and foint Surgery, 52B, 704-716. 